\title{
Effects of thermal treatments on ascorbic acid content of leafy vegetables: An in vitro analysis
}

\section{Nupur Mehrotra}

Department of Biochemistry, SVKM's Mithibai College of Arts, Chauhan Institute of Science and Amrutben Jivanlal College of Commerce and Economics (Autonomous), Vile-Parle (West), Mumbai-400056, Maharashtra, India

\section{Article Info}

\section{Article history}

Received 10 February 2021

Revised 13 March 2021

Accepted 15 March 2021

Published Online 30 March 2021

\section{Keywords}

Medicinal plants

Blanching

Steaming

Microwave cooking

Ascorbic acid

\begin{abstract}
The green leafy vegetables are packaged with nutritional and medicinal benefits for holistic wellbeing which can be contributed to presence of phytochemicals and micronutrients. Processing of food, affects the nutritional value, concentration, and biological activities of all components to different extent. In this perspective, the content of antioxidant activity in unprocessed food in relation to that in processed foods requires attention and has emerged as an important parameter to assess product quality. Further, most vegetables are consumed post cooking, though a few like green leafy ones are consumed raw, as in salads. This study aims to evaluate the effect of different cooking methods on the content of vitamin C in five most commonly used green leafy vegetables, viz., Spinacia oleracea L. or palak, Raphanus sativus L. or radish, Trigonella foenum-graecum L or fenugreek or methi, Coriandrum sativum L. or coriander or dhaniya and Anethum graveolens L.or shepu or sooa.

Domestic heating methods used were blanching, steaming, and microwaving. Vitamin $\mathrm{C}$ was estimated through titrimetry and the results suggest that different methods of cooking result in significant reduction in ascorbic content in all five leafy vegetables with microwaving cooking accounting to maximum loss for all five samples. Highest vitamin C loss on blanching was in fenugreek (51.04 \%), followed by shepu leaves $(45.35 \%)$, coriander $(44.64 \%)$, radish leaves $(16.67 \%)$ and spinach $(15.68 \%)$ while on steaming, highest loss of vitamin $\mathrm{C}$ amongst selected vegetable occurred in fenugreek leaves $(35.77 \%)$, followed by radish leaves $(33.34 \%)$, coriander leaves $(25.67 \%)$, shepu $(22.74 \%)$, spinach leaves $(17.58 \%)$. It, thus could be concluded that cooking by boiling with microwaving, steaming and blanching decreases the vitamin $\mathrm{C}$ contents in green leafy vegetables, and needs to be considered, so as to make available ascorbic acid, maximally.
\end{abstract}

\section{Introduction}

Vegetables and fruits comprise an important constituent of humans need for food. They are rich in fibers, vital vitamins, minerals along with presence of phytochemicals, known for their medicinal properties which helps in maintenance of good health. Plant origin food is rich in natural antioxidants which facilitates scavenging of free radicals, which help to combat degenerative diseases. Enrichment of the body's antioxidant status can be achieved by increasing consumption of vegetables rich in vitamins (Gunathilake et al., 2018); carotenoids and polyphenols, which too possess antioxidant properties (Andarwulan et al., 2012; Gunathilake et $a l ., 2016)$ and are present in the green leafy ones. However, these are generally not preferred to be eaten raw due to high cellulose content and so are consumed post cooking, and cooking impacts their nutritive value (Zhang et al., 2011).

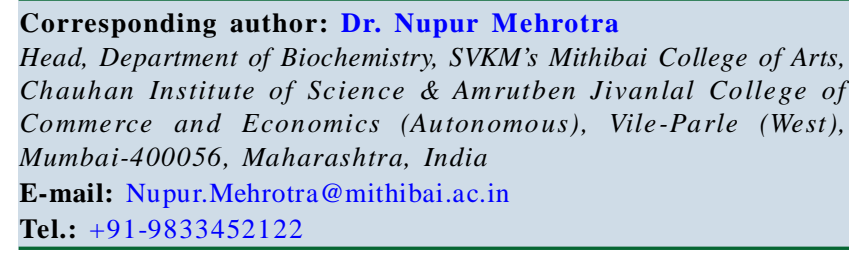
Copyright () 2021 Ukaaz Publications. All rights reserved. Email: ukaaz@yahoo.com; Website: www.ukaazpublications.com
Fabbri and Crosby (2016) have reported that choice of cooking methods can improve the nutrients availability. The common methods used for vegetable cooking include boiling, steaming, sauteing, roasting, frying, pressure cooking and microwaving, though initial preparation procedures as washing, peeling, cutting, chopping, and soaking also affect the nutrient content (Oboh, 2005). The extent of the loss of antioxidants as ascorbic acid is dependent on the cooking methods along with the time required for cooking. Cooking green leafy vegetables at high temperature is most likely to destroy ascorbic acid, due to it being heat labile, photosensitive as well as water soluble which also leads to easy leaching into the cooking water (Bembem and Sadana, 2014). In green leavy vegetables, not only ascorbic acid but even carotenoids are highly sensitive to heat and their storage over extended times can also lead to loss of these nutrients (Hollman et al., 1995). On the other hand, the phenolic compounds and the flavonoids are comparatively stable even at elevated temperature and can be stored without degradation over longer storage periods (Morand et al., 2000).

Methods used for culinary preparations mediate marked effects on the foods nutrient content. For example, a significant loss in polyphenols happens due to peeling of fruit and vegetables as these substances are present close to the surface which is lost due to peeling (Manach et al., 2004). Similarly, grinding of plant tissues leads to oxidative degradation of polyphenols as due to cell rupture 
direct contact is facilitated between cytoplasmic polyphenol oxidase and polyphenols. Further, polyphenols polymerize to different degrees into brown pigments (Macheix and Fleuriet, 1998). Cooking of vegetables influences significant changes in the overall chemical composition and concentration as well as on the bioavailability of bioactive compounds. Studies have reported both positive and negative effects on nutritional changes due to cooking, depending upon processing conditions and morphological characteristics of vegetable species (Ou and Huang, 2002). Hollman et al. (1997) had suggested that not only cooking methods but even processing methods as sterilizing, blanching, freezing, and canning, affect the yield, chemical composition and bioavailability of antioxidants.

Gupta et al. (2008) reported that greens as amaranth, spinach, fenugreek, shepu, bathua, drumstick, keerae, and kilkeerae, on being blanched for a minute at $80^{\circ} \mathrm{C}$, showed lesser retention of ascorbic acid (10-20\%), while brahmi and ambat chukka showed highest retention (70-75\%). With an increase in the blanching time by another minute, in drumstick, bathua, and brahmi, additional loss of 5 to $20 \%$ was observed which was marginal in others. The retention of ascorbic acid content ranged from 11-26\% in spinach, amaranth, brahmi and kilkeerae, being $45-85 \%$ in remaining greens, if blanched with steam for $5 \mathrm{~min}$. Using a microwave oven for blanching for a minute, showed $60 \%$ retention of ascorbic acid in bathua, and ambat chukka while it was 17 to $40 \%$ in others. Bembem et al. (2014) studied effect of cooking methods as boiling, steaming, micro wave cooking, pressure cooking, and sautéing on vitamin $\mathrm{C}$ and phenolic content of Indian mustard leaves.The findings suggested that the cooking procedures lead to reducedthe vitamin $\mathrm{C}$ content with the lowest retention of vitamin C , observed in sautéed sample (20.3\%) $<$ microwave cooking $(26.6 \%)<$ pressure cooking $(30.9 \%)<$ boiling $(30.8 \%)<$ steaming $(30.8 \%)$. The effect of time required for boiling $(5,10,15$ and 20 minutes) selected green vegetables, viz., Brassica oleracea (cabbage), Solanum torvum (abeduru), Corchorus olitorius ayoyo, Xanthosoma sagittifolium (nkontomire) and Abelmoschus esculentus (okro), on the vitamin C content was studied by Agbemafle et al. (2012). The loss of vitamin $\mathrm{C}$ content with increasing boiling time was in the range of $42 \%$ to $85 \%$. The least loss was in Abelmoschus esculentus (42.74\%), followed by Brassica oleracea (47.56\%), Xanthosoma sagittifolium (52.03\%), Solanum torvum $(69.71 \%)$ and highest being in Corchorus olitorius (85.33\%).

This study is aimed at enriching in ourselves with the effect of various methods for cooking leafy greens in relation to ones of Indian origin. It aims to investigate the influence of cooking on selected leafy vegetables, namely; spinach, radish, fenugreek, coriander and shepu, on the ascorbic acidcontent.

\section{Materials and Methods}

\subsection{Cooking treatment}

The samples were subjected to three common cooking methods used by the Indian households, i.e., blanching, steaming, and microwave cooking. Blanching is performed by dipping vegetables briefly in boiling water to get them partially cooked, followed by immersing in cold water while in steaming the vegetables are cooked over boiling water with no direct contact with water. Cooking green leafy vegetables using microwave can be achieved using 2500 watt at $180-220^{\circ} \mathrm{C}$.

\subsubsection{Blanching}

$0.5 \mathrm{gm}$ leaves of selected vegetable were placed in $50 \mathrm{ml}$ of boiling water and blanched for $2 \mathrm{~min}$. Thereafter, samples were cooled using $50 \mathrm{ml}$ tap water.

\subsubsection{Steaming}

$0.5 \mathrm{gm}$ leaves of selected vegetable were placed on a perforated tray over a borosil flask and steamed using $50 \mathrm{ml}$ of boiling water for 2 min. The leaves did not come in direct contact of water.

\subsubsection{Microwaving}

$0.5 \mathrm{gm}$ leaves of selected vegetable were cooked in a microwave oven in $50 \mathrm{ml}$ of water on a high heat for $2 \mathrm{~min}$.

\subsection{Extraction}

The cooked as well as raw samples (control) of the selected leafy vegetable were ground with a mortar and pestle using $10 \mathrm{ml}$ of $50 \%$ ethanol and then filtered through 4 layers of muslin cloth. The filtrates, thus obtained was centrifuged for $20 \mathrm{~min}$ at $3000 \mathrm{rpm}$, to remove alldebris.This supernatant was then taken for the study.

\subsection{Chemical analysis}

After extraction, the supernatants were collected and analyzed immediately for ascorbic acid content using DCPIP method suggested by Külen et al. (2013). Samples were prepared in 5 replicates and were analyzed in triplets. The vitamin $\mathrm{C}$ content was expressed in $\mathrm{mg} / 100 \mathrm{~g}$.

Results are expressed as: Amount of ascorbic acid mg/100 gm sample $=\left(0.08 \mathrm{mg} / \mathrm{V}_{1} \mathrm{ml}\right) \times\left(\mathrm{V}_{2} \mathrm{ml} / \mathrm{Wt}\right.$. of the sample $) \times 100$.

where $V_{1}$ was titrimetric reading for standard and $V_{2}$ for the sample.

\subsection{Statistical analysis}

The data is represented as Mean \pm standard error of the mean (SEM). Further, statistical analysis was performed using the Student's t-test and $p<0.05$ was statistically significant.

\section{Results}

The ascorbic acid concentrations were calculated in raw as well as samples cooked using steaming, blanching, and microwaving. All the five varieties of green leafy vegetables selected reported good ascorbic acid concentration and the cooking led to a reduction in the same. The percentage loss of ascorbic acid in fenugreek leaves after subjecting it to different heat temperatures was more pronounced in microwaved $(62.53 \%)$, followed by blanched $(51.42 \%)$ and steamed $(36.27 \%)$ fenugreek leaves. For spinach, the loss of ascorbic acid was in the order microwaved spinach $(33.91 \%)>$ steamed spinach $(18.65 \%)$; coriander $(25.04 \%)$. For coriander, the maximum loss was in microwaved coriander leaves $(50.08 \%)$, followed by blanched $(45.14 \%)$ and steamed coriander leaves $(25.04 \%)$. For radish and shepu too, maximum loss was in microwaved leaves $(35.73 \%)$ and $(63.08 \%)$, respectively with minimum in blanched $(18.13 \%)$ and $(22.40 \%)$ in radish and shepu, respectively (Table 1 and Figures 1 and 2). 
Table1: Ascorbic acid content of raw and cooked leafy vegetables

\begin{tabular}{|c|c|c|c|c|c|c|}
\hline Sample & $\begin{array}{r}\text { Ascorbic acid } \\
\text { mg/100 gms }\end{array}$ & $\begin{array}{c}\text { Percentage } \\
\text { loss }(\%)\end{array}$ & $\begin{array}{r}\text { Ascorbic acid } \\
\text { mg/100 gms }\end{array}$ & $\begin{array}{c}\text { Percentage } \\
\text { loss }(\%)\end{array}$ & $\begin{array}{c}\text { Ascorbic acid } \\
\text { mg/100 gms }\end{array}$ & $\begin{array}{c}\text { Percentage } \\
\text { loss }(\%)\end{array}$ \\
\hline \multicolumn{3}{|c|}{ Trigonella foenum-graecum L. } & \multicolumn{2}{|c|}{ Coriandrum sativum L. } & \multicolumn{2}{|c|}{ Anethum graveolens $\mathrm{L}$. } \\
\hline Raw & $24.29 \pm 0.02$ & - & $6.07 \pm 0.01$ & - & $56.72 \pm 1.35$ & - \\
\hline Blanched & $11.08 \pm 1.27$ & $51.42 *$ & $3.33 \pm 0.68$ & $45.14 *$ & $30.96 \pm 1.35$ & $45.41 *$ \\
\hline Steamed & $15.48 \pm 0.68$ & $36.27 *$ & $4.55 \pm 0.01$ & $25.04 *$ & $44.01 \pm 1.52$ & 22.40 \\
\hline Microwave & $09.01 \pm 0.01$ & $62.53 *$ & $3.03 \pm 0.01$ & $50.08 *$ & $20.94 \pm 1.27$ & $63.08 *$ \\
\hline \multicolumn{3}{|c|}{ Spinacia oleracea $\mathrm{L}$. } & \multicolumn{2}{|c|}{ Raphanus sativus L. } & & \\
\hline Raw & $17.90 \pm 0.67$ & - & $8.50 \pm 0.83$ & - & & \\
\hline Blanched & $15.17 \pm 0.01$ & 15.25 & $6.95 \pm 0.81$ & $18.13 *$ & & \\
\hline Steamed & $14.56 \pm 0.83$ & 18.65 & $5.46 \pm 1.83$ & $35.73 *$ & & \\
\hline Microwaved & $11.83 \pm 0.67$ & $33.91 *$ & $5.46 \pm 1.832$ & $35.73^{*}$ & & \\
\hline
\end{tabular}

Mean \pm Standard Error $(\mathrm{SEM})$ where $\mathrm{n}=5$; Mean values superscripted by*are statistically significant in comparison to raw vegetables, at $p<0.05$

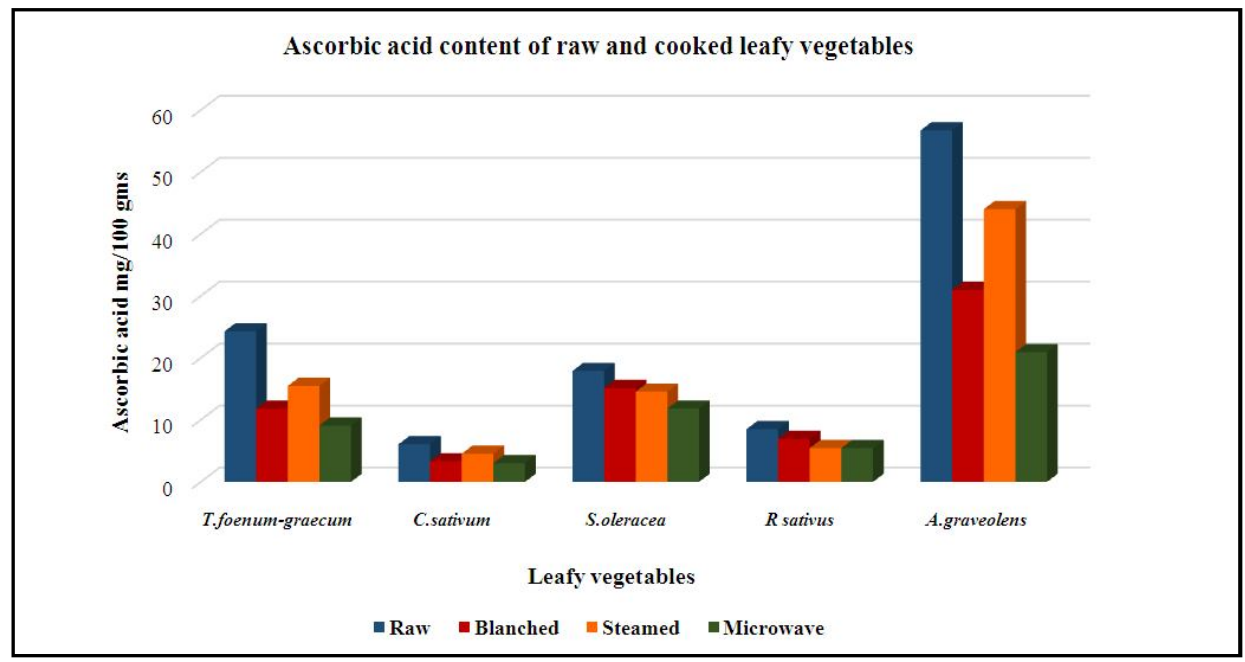

Figure 1: Ascorbic acid content of raw and cooked leafy vegetables.

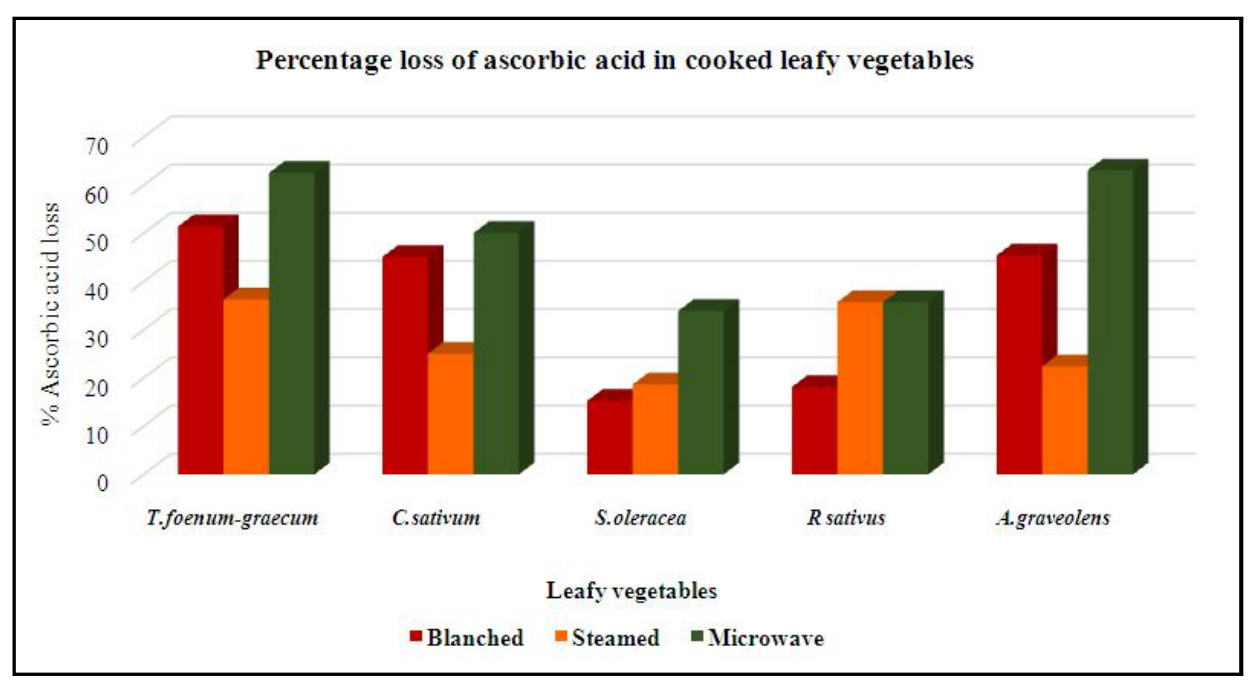

Figure 2: Percentage loss of ascorbic acid in cooked leafy vegetables. 
As ascorbic acid is a water-soluble nutrient, it was expected that the water used for cooking using blanching or microwaving, would have some vitamin $\mathrm{C}$ content leached out. The ascorbic acid content of water used for cooking was maximum for blanched shepu and minimum for microwaved radish, coriander and fenugreek (Table 2 and Figure 2).

Table 2: Vitamins $\mathrm{C}$ content present in water used for cooking treatments

\begin{tabular}{|l|c|c|c|c|c|}
\hline Sample & \multicolumn{4}{|c|}{ Ascorbic acid mg/100 ml of sample water } \\
\hline & $\begin{array}{c}\text { Trigonella foenum- } \\
\text { graecum L. }\end{array}$ & $\begin{array}{c}\text { Coriandrum } \\
\text { sativum } \text { L }\end{array}$ & $\begin{array}{c}\text { Spinacia } \\
\text { oleracea } \text { L. }\end{array}$ & $\begin{array}{c}\text { Raphanus } \\
\text { sativus } \text { L. }\end{array}$ & $\begin{array}{c}\text { Anethum } \\
\text { graveolens } \text { L. }\end{array}$ \\
\hline Blanched & 0.25 & 0.25 & 0.38 & 0.25 \\
Microwaved & 0.12 & 0.12 & 0.44 & 0.12 \\
\hline
\end{tabular}

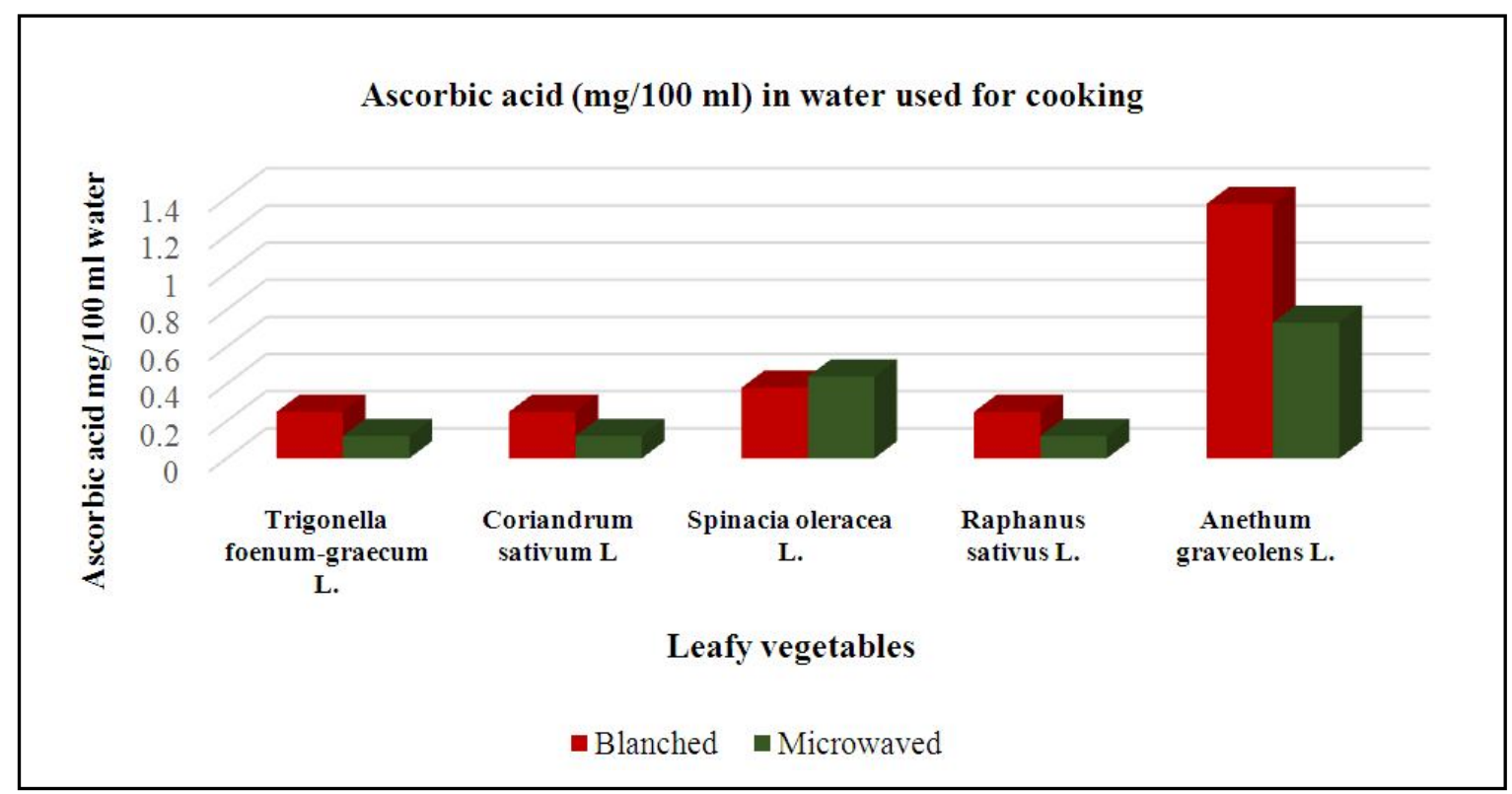

Figure 3: Vitamins $\mathrm{C}$ content present in water used for cooking treatments.

\section{Discussion}

Traditionally, in the Indian subcontinent and in other developing countries, green leafy vegetables play a major role in providing nutrition (Sreeramulu et al., 2009), as these leafy vegetables are a rich source of antioxidants and selected micronutrients in Indian diets. Biologically active compounds, like ascorbic acid and phenols, contribute to antioxidant activity of vegetables.

Ascorbic acid has proven to be protective against multiple types of cancers as oral cavity, esophagus, and stomach. Maintenance of blood vessel flexibility with an improvement in arterial blood circulation in smokers, has also been attributed to ascorbic acid.Vitamin $\mathrm{C}$, a water soluble antioxidant scavenges aqueous peroxyl radicals before they damage lipids (Rice and Miller, 1995).

Generally, cooking often is conducted on convenience and taste rather than taking consideration of retention of nutrients and healthpromoting compounds (Masrizal et al., 1997). Domestic processing and cooking of vegetables leads to a change in chemical composition of nutrients, and significantly affects the bioavailability of phytochemicals. Since plant foods are regularly consumed in cooked forms, polyphenol and ascorbic acid intakes calculated based on their content in raw foods are likely to be inaccurate. Literature seems to have few data on the antioxidant activity and polyphenolic content of cooked Indian plant foods (Sreeramulu et al., 2013).

Therefore, it was considered pertinent to study the effect of heat treatment on the ascorbic acid and phenolic content of some Indian greens rich in these activities. The green leafy vegetables selected for the study were $S$. oleracea (spinach), A. graveolens (shepu), $C$. sativum (coriander leaves), R. sativus (radish leaves) and $T$. foenum-graecum (fenugreek leaves) while the cooking methods selected were blanching, steaming and microwave cooking. These green leafy vegetables are popular, abundantly available and commonly consumed by urban and rural Indians.

In the present study, content of vitamin $\mathrm{C}$ in raw green leafy vegetables ranged from $6.07 \mathrm{mg}$ (coriander leaves) $/ 100 \mathrm{~g}$ of vegetable to $56.72 \mathrm{mg}$ (shepu leaves)/100 $\mathrm{g}$ of vegetable. However, a significant loss of vitamin C, post cooking was observed, as it is well established that being thermo labile vitamin C content is lost (Nagy and Smooth, 1977). 
Ascorbic acid content of greens under study on being blanched for 2 min, showed a reduction, though the extent of loss varied between the vegetables. Reduction of ascorbic acid was comparatively higher in fenugreek leaves $(51.42 \%)$, moderate in shepu $(45.41 \%)$, and corianders leaves $(45.14 \%)$ and lower in radish leaves (18.13\%) and spinach leaves $(15.25 \%)$. The results are in accordance with those reported by Begum et al. (2009), wherein on blanching Moringa oleifera for $15-20 \mathrm{~min}$, decreased vitamin $\mathrm{C}$ level by $21-50 \%$ was observed, as ascorbic acid leached into the water used for blanching. Due to boiling, blanching, pressure cooking stewing and frying, losses in vitamin C have been reported (Yadav and Sehgal, 1995, 1997). The results of the present study also fall in line with the findings of Gupta et al. (2008) suggestive of that when greens were blanched at $80^{\circ} \mathrm{C}$ for $1 \mathrm{~min}$, loss of ascorbic acid was observed.

On microwave cooking for $2 \mathrm{~min}$, shepu and fenugreek leaves showed more loss of ascorbic acid (63.08\% and $62.53 \%$, respectively), followed by coriander leaves $(50.08 \%)$, radish leaves $(35.73 \%)$ and spinach leaves $(33.91 \%)$ in the present study. The results are at par with the findings of Bembem et al. (2014), Zhang and Hamauzu (2004) and Gliszczynska et al. (2006), wherein remarkable losses in content of vitamin $\mathrm{C}$ were reported on microwave cooking. Yasmin and Rajam (2013) have reported 40\% loss in ascorbic acid in spinach leaves on subjecting it to microwave cooking.

In the present study, steaming was observed to retain maximum percentage of ascorbic acid in the selected green vegetables compared to blanching and microwave cooking. Reduction of ascorbic acid was highest in fenugreek leaves $(36.27 \%)$, followed by radish leaves $(35.73 \%)$, coriander leaves $(25.04 \%)$, shepu leaves $(22.40 \%)$, and spinach leaves $(18.65 \%)$. Thus, the main advantage of steaming is to reduce leaching of solutes from the vegetable. Vallejo et al. (2002) and Yuan et al. (2009) also inferred that for broccoli steaming caused less loss of vitamin $\mathrm{C}$ than boiling and microwaving.

Vitamin $\mathrm{C}$ being water soluble, leaches out into surrounding water during blanching and microwave cooking. Leaching of vitamin $\mathrm{C}$ content from the vegetables into the cooking water was also determined in the present study. Vitamin $\mathrm{C}$ leached out in water used for blanching these five vegetables, ranged from $0.25-1.37 \mathrm{mg} /$ $100 \mathrm{ml}$ of sample water in the order shepu $(1.37 \mathrm{mg})>$ spinach $(0.38$ $\mathrm{mg})>$ coriander, radish leaves, fenugreek $(0.25 \mathrm{mg})$ while during microwave cooking it was shepu $(0.73 \mathrm{mg})>$ spinach $(0.44 \mathrm{mg})>$ coriander, radish leaves and fenugreek $(0.12 \mathrm{mg})$. Similar findings were obtained by Fennema (1997), who reported that cooking procedures lead to significant losses of vitamin $\mathrm{C}$, mainly due toleaching.

\section{Conclusion}

The results of the present study demonstrate that the ascorbic acid content, declined drastically post heat treatments. These findings confirm that thermal processing results in maximum losses of highly water soluble ascorbic acid. Parameters as initial ascorbic acid content, surface area, mechanical damage, as well as enzymatic activities lead to ascorbic acid loss from the leafy vegetables (Gupta, 2008). The chief causes for losses in vitamin $C$, content its water solubility, thermo liability, and enzymatic oxidation during food processing. Being a sensitive micronutrient, even at low temperature, vitamin $\mathrm{C}$ content decreases as time of storage period increases.
As green leafy vegetables play such an important role, the methods of preparation should be considered. Based on the results of the present study, all green leafy vegetables were cooked for 2 min wherein steam cooking was the method that best retained the ascorbic acid content compared to blanching and microwave cooking.

\section{Acknowledgements}

Financial and infrastructural support to the Department of Biochemistry from Shri Vile Parle Kelavani Mandal (SVKM) and Mithibai College (Autonomous) is gratefully acknowledged.

\section{Conflict of interest}

The author declares that there is no conflict of interest relevant to this article.

\section{References}

Agbemafle, R., Obodai, Adukpo, G. and Amprako, D. (2012). Effects of boiling time on the concentrations of vitamin $\mathrm{C}$ and beta-carotene in five selected green vegetables consumed in Ghana. Advances in Applied Science Research, 3(5):2815-2820.

Andarwulan, N.; Kurniasih, D.; Apriady, R.A.; Rahmat, H. and Roto, A.V. (2012). Bolling, B.W. polyphenols, carotenoids, and ascorbic acid in underutilized medicinal vegetables. J. Funct. Foods, 4:339-347.

Begum, S.A.; Ahmed, M.F. and Rahman, M. (2009). Effect of cooking temperature and storage period on preservation of water soluble vitamin C content in Citrus macroptera and Moringa oleifera lunk. Asian Journal of Food Argoindustry, 2(03):255-261.

Bembem, K. and Sadana, B. (2014). Effect of cooking methods on thenutritional composition and antioxidant activity of potatotubers. International Journal of Food and Nutritional Sciences, 2(4):26-30.

Bembem, K., Sadana, B. and Bains, K. (2014). Effect of domestic cooking methods on the nutritive and antioxidative components of mustard leaves (Brassica juncea). International Journal of Food, Agriculture and Veterinary Sciences, 4:ISSN:2277-209X.

BoxinOu, Dejian Huang, Maureen Hampsch-Woodill, Judith A. Flanagan, and Elizabeth K. Deemer, (2002). Analysis of antioxidant activities of common vegetables employing oxygen radical absorbance capacity (ORAC) and ferric reducing antioxidant power (FRAP) Assays: A comparative study Journal of Agricultural and Food Chemistry, 50(11):3122-3128

Catherine A. Rice-evans, Nicholas J. Miller, Paul G. Bolwell, Peter M. Bramley and John B. Pridham (1995). The relative antioxidant activities of plant-derived polyphenolic flavonoids, Free Radical Research, 22(4):375-383

Fabbri, A.D. T. and Crosby, G. A., (2016). A review of the impact of preparation and cooking on the nutritional quality of vegetables and legumes. International Journal of Gastronomy and Food Science, 3:2-11.

Fennema, O. (1997). Loss of vitamins in fresh and frozen foods. Food Technology, 31(12):32-38.

Gliszczynska-Swiglo, A., Ciska, E., and Pawlak-Lemanska, K. (2006). Changes in the content of health-promoting compounds and antioxidant activity of broccoli after domestic processing. Food Additives and Contaminants, 23(11):1088-1098. 
Gunathilake, K.D.P.P. and Ranaweera, K.K.D.S. (2016). Antioxidative properties of 34 green leafy vegetables. J. Funct. Foods, 26:176-186.

Gunathilake, K.D.P.P.; Ranaweera, K.K.D.S. and Rupasinghe, H.P.V. (2018) Change of phenolics, carotenoids, and antioxidant capacity following simulated gastrointestinal digestion and dialysis of selected edible green leaves. Food Chem., 245:371-379.

Gupta, S., Lakshmi, A. and Prakash, J. (2008). Effect of different blanching treatments on ascorbic acid retention on green leafy vegetables. Natural Product Radiance, 7(2):111-116.

Külen, O.; Stushnoff, C. and Holm, D.G., (2013). Effect of cold storage on total phenolics content, antioxidant activity and vitamin $\mathrm{C}$ level of selected potato clones. J. Sci. Food Agric., 93:2437-2444.

Masrizal, M., Giraud, D. and Driskell, J. (1997). Retention of vitamin C, iron, and beta-carotene in vegetables prepared using different cooking methods. Journal of Food Quality, 20:403-418.

Oboh, G, (2005). Effect of blanching on the antioxidant properties of some tropical green leafy vegetables. LWT Food Sci. Technol., 38:513-517.

Sreeramulu D, Reddy, C.V.K., and Raghunath, M. (2009). Antioxidant activity of commonly consumed cereals, millets, pulses and legumes in India. Indian Journal of Biochemistry and Biophysics, 46(1):112-115.

Steven Nagy and John M. Smoot, (1977). Temperature and storage effects on percent retention and percent U.S. recommended dietary allowance of vitamin $\mathrm{C}$ in canned single-strength orange juice. Journal of Agricultural and Food Chemistry, 25(1):135-138.
Vallejo, F., Tomas-Barberan, F., and Garcia-Viguaera, C. (2002). Glucosinolates and vitamin $\mathrm{C}$ content in edible parts of broccoli florets after domestic cooking, European Food Research and Technology, 215 (4):310-316.

Yadav, S. K. and Sehgal, A. (1995). Effect of home processing on ascorbic acid and beta-carotene content of spinach (Spinachia oleracia) and amaranth (Amaranthus tricolor) leaves. Plant Foods for Human Nutrition, 47:125-131.

Yadav, S. K. and Sehgal, A. (1997). Effect of home processing on ascorbic acid and beta-carotene content of bathua (Chenopodium album) and fenugreek (Trigonella foenumgraecum) leaves. Plant Foods for Human Nutrition, 50:239-247.

Yasmin, A. and Rajam. S. (2013). Analysis of selected micronutrients before and after leaching of spinach and amaranth gangeticus, processed by different cooking methods. Indian Journal of Research, 2(2):110-117.

Yuan, G. F., Sun, B. and Yuan, J. (2009). Effects of cooking methods on health-promoting compounds of broccoli. Journal of Zhejiang University Science, 10(8):580-588.

Zhang, M.; Hettiarachchy, N.S.; Horax, R.; Kannan, A.; Praisoody, A. and Muhundan, A., (2011). Phytochemicals, the antioxidant and antimicrobial activity of Hibiscus sabdariffa, Centella asiatica, Moringa oleifera and Murrayakoenigii leaves. J. Med. Plants Res., 5:6672-6680.

Nupur Mehrotra (2021). Effects of thermal treatments on ascorbic acid content of leafy vegetables: An in vitro analysis. J. Phytonanotech. Pharmaceut. Sci., 1(1):10-15. http://dx.doi.org/10.21276/jpps.2021.1.1.3 